\title{
A One- Dimensional Bio-Heat Transfer Equation with Galerkin FEM in Cylindrical Living Tissue
}

\author{
Hem Raj Pandey
}

Faculty of Science and Technology, School of Engineering,

Pokhara University, Nepal

Email Address: rajhem2040@gmail.com

\begin{abstract}
A one-dimensional steady state bio-heat transfer model of temperature distribution in cylindrical living tissue is discussed using numerical approximation technique the Galerkin Finite element method.

we observe the effects of the thermal conductivity of the thermal system. The results show that the derived solution is useful to easily and accurately study the thermal behavior of the biological system, and can be extended to such applications as parameter measurement, temperature field reconstruction and clinical treatment.
\end{abstract}

Keywords: Pennes' Bio-heat transfer equation, Galerkin Finite Element Method.

\section{Introduction}

The normal body core temperature is $37^{0} \mathrm{C}$. This body temperature is the result of equilibrium between heat production and heat loss. If the body temperature stretches so far from normal temperature, death will occur. The temperature nearly $27^{\circ} \mathrm{C}$ and below and nearly $42^{\circ} \mathrm{C}$ and above are critical, so the temperature of body should be maintained around $37^{\circ} \mathrm{C}$. The maintenance of body temperature is a dynamic system. If heat is greater than heat production then the body core temperature drops. Likewise if heat loss is less than heat production then the core temperature rises. So, the rise or drop in core temperature is equally dangerous, so body temperatures are kept constant $[1,3,4,5]$.

In this paper, we study the effect of thermal parameters of dermal part in cylindrical living tissue. The linear function is considered. The outer surface of the body is exposed to the environment and the loss of heat from the skin surface is assumed due to convection and radiation. Here, we neglected the axial and angular direction and considered only the radial direction steady state model. The numerical result(Finite Galerkin Finite Element Method[8]) obtained is exhibited graphically by applying the suitable values of physical and physiological parameters.

\section{Model Formulation}

Mathematical model used for bio-heat transfer is based on Pennes' equation[7]. The Pennes' model is preferable for the study of heat transfer between blood and tissue which also associates the effect of metabolism and blood perfusion. The Pennes' equation is written as;

$$
\rho c \frac{\partial T}{\partial t}=\nabla \cdot(K \nabla T)+\rho_{b} w_{b} c_{b}\left(T_{a}-T\right)+q_{m}
$$


where, $\mathrm{T}\left({ }^{0} \mathrm{C}\right)$ denotes the temperature of tissue element at any time $\mathrm{t}$ at a distance of $\mathrm{x}$ measured perpendicularly into the tissue element from the skin surface, and $\rho, \mathrm{c}, \mathrm{k}$ are the $\operatorname{density}\left(\mathrm{Kg} / \mathrm{m}^{3}\right)$, the specific heat $\left(\mathrm{J} / \mathrm{Kg} .{ }^{0} \mathrm{C}\right)$ and the thermal conductivity of tissue $\left(\mathrm{W} / \mathrm{m} .{ }^{0} \mathrm{C}\right)$ respectively. $\mathrm{w}_{\mathrm{b}}$ is the blood perfusion rate per unit volume $\left(\mathrm{Kg} / \mathrm{s} \cdot \mathrm{m}^{3}\right), \mathrm{c}_{\mathrm{b}}$ is the specific heat of $\operatorname{blood}\left(\mathrm{Kg} / \mathrm{m}^{3}\right), \mathrm{q}_{\mathrm{m}}$ is the metabolic heat generation per unit volume $\left(\mathrm{W} / \mathrm{m}^{3}\right), \mathrm{T}_{\mathrm{a}}$ represents the temperature of arterial blood $\left({ }^{0} \mathrm{C}\right)$ and $\mathrm{T}$ is the tissue temperature $\left({ }^{0} \mathrm{C}\right)$.

The equation (1)in the cylindrical coordinate system is

$$
\rho \mathrm{c} \frac{\partial \mathrm{T}}{\partial \mathrm{t}}=\frac{1}{\mathrm{r}} \frac{\partial}{\partial \mathrm{r}}\left(\mathrm{Kr} \frac{\partial \mathrm{T}}{\partial \mathrm{r}}\right)+\frac{1}{\mathrm{r}^{2}} \frac{\partial}{\partial \mathrm{r}}\left(\mathrm{K} \frac{\partial \mathrm{T}}{\partial \theta}\right)+\frac{1}{\mathrm{r}} \frac{\partial}{\partial \mathrm{z}}\left(\mathrm{K} \frac{\partial \mathrm{T}}{\partial \mathrm{z}}\right)+\mathrm{M}\left(\mathrm{T}_{\mathrm{a}}-\mathrm{T}\right)+\mathrm{q}_{\mathrm{m}}
$$

The one dimensional steady state bio heat equation of cylindrical living tissue reduces to

$$
\frac{1}{\mathrm{r}} \frac{\mathrm{d}}{\mathrm{dr}}\left(\mathrm{Kr} \frac{\mathrm{dT}}{\mathrm{dr}}\right)+\mathrm{M}\left(\mathrm{T}_{\mathrm{a}}-\mathrm{T}\right)+\mathrm{q}_{\mathrm{m}}=0
$$

where boundary conditions are:

$$
\mathrm{r}=0, \quad \frac{\mathrm{dT}}{\mathrm{dr}}=0
$$

and

$$
\mathrm{r}=\mathrm{R}, \quad-\mathrm{K} \frac{\partial \mathrm{T}}{\partial \mathrm{r}}=\mathrm{h}_{\mathrm{A}}\left(\mathrm{T}-\mathrm{T}_{\infty}\right)
$$

where $\mathrm{R}$ is the radius of concerned tissue, $h_{A}$ is the coefficient of heat transfer,

and $T_{\infty}$ is ambient temperature.

\section{Galerkin Finite Element Method}

The Finite Element Method is a powerful numerical technique for solving the algebraic, differential, and integral equations. The finite element method provides an approximate solution. The domain of the physical problem is discretized into the finite elements. The elements are connected at points called nodes. The assemblage of elements is called finite element mesh.

Several approaches can be used to transform the physical formulation of the problem to its finite element discrete analogue. Mostly, we have Galerkin weighted residue method and variational method. There may be other ways to apply the Galerkin method, and these would not necessarily be the same as a variational method. The variational method cannot always be applied because there may be no variational principle for the problem, but the Galerkin method is always applicable because it does not depend on the existence of a variational principle.

In Galerkin approach we have the strong and weak formulation. Strong Form is the set of governing partial and ordinary differential equation with boundary condition's are the strong form. The strong solution must satisfies the differential equation and boundary conditions exactly and must be as smooth(number of continuous derivatives) as required by the differential equation. If the system under analysis consists of varying geometry or material properties, then discontinuous functions will enter into the equations of motion and the issue of differentiability can become immediately apparent. To avoid such difficulties, we can change the strong form of the governing dynamics into a weak or weighted-integral formulation. Weak form is a variational statement of the problem in which we integrate against a test (weight) function.[8] 
Using weak Formulation of Galerkin Finite Element Methods(FEM)[8] with $r_{a}=0$ and $r_{b}=R$ in the equation (3), we get

$$
\int_{\mathrm{r}_{\mathrm{a}}}^{\mathrm{r}_{\mathrm{b}}} \mathrm{w}\left[\frac{1}{\mathrm{r}} \frac{\mathrm{d}}{\mathrm{dr}}\left(\mathrm{kr} \frac{\mathrm{dT}}{\mathrm{dr}}\right)+\mathrm{M}\left(\mathrm{T}_{\mathrm{a}}-\mathrm{T}\right)+\mathrm{q}_{\mathrm{m}}\right] \mathrm{dr}=0 \text { (4) }
$$

putting $\mathrm{a}=\mathrm{kr}$ and Integrating equation (10) we get

$$
\int_{r_{a}}^{r_{b}}\left[w \frac{d}{d r}\left(a \frac{d T}{d r}\right)+\operatorname{Mwr}\left(T_{a}-T\right)+q_{m} w r\right] d r=0
$$

After simplified and using the trial function into equation(11) we get

$$
\left[\mathrm{K}^{\mathrm{e}}\right]\left\{\mathrm{T}^{\mathrm{e}}\right\}=\left\{\mathrm{f}^{\mathrm{e}}\right\}+\left\{\mathrm{Q}^{\mathrm{e}}\right\}(6)
$$

where, $K_{i j}^{e}=\int_{r_{a}}^{r_{b}}\left[a \frac{d \psi_{i}^{e}}{d r} \frac{d \psi_{j}^{e}}{d r}-M \psi_{i}^{e} \psi_{j}^{e} r\right] d r, f_{i}^{e}=\int \psi_{i}^{e}$ frdr,$f=M T_{a}+q_{m}$

Let the linear function be $\psi_{1}^{e}=\frac{\mathrm{r}_{\mathrm{b}}-\mathrm{r}}{\mathrm{h}_{\mathrm{e}}}$ and $\psi_{2}^{\mathrm{e}}=\frac{\mathrm{r}-\mathrm{r}_{\mathrm{a}}}{\mathrm{h}_{\mathrm{e}}}$. Using explicit form $\mathrm{a}=\mathrm{a}_{\mathrm{e}} \mathrm{r}, \mathrm{f}=\mathrm{f}_{\mathrm{e}}$ and $r=r_{a}+\bar{r}$. Thus we get

$$
\begin{aligned}
& \mathrm{K}_{11}^{\mathrm{e}}=\frac{\mathrm{a}_{\mathrm{e}}}{\mathrm{h}_{\mathrm{e}}}\left(\mathrm{r}_{\mathrm{a}}+\frac{\mathrm{h}_{\mathrm{e}}}{2}\right)+\frac{M h_{\mathrm{e}}}{12}\left(4 \mathrm{r}_{\mathrm{a}}+\mathrm{h}_{\mathrm{e}}\right), \mathrm{K}_{12}^{\mathrm{e}}=-\frac{\mathrm{a}_{\mathrm{e}}}{\mathrm{h}_{\mathrm{e}}}\left(\mathrm{r}_{\mathrm{a}}+\frac{\mathrm{h}_{\mathrm{e}}}{2}\right)+\frac{M h_{\mathrm{e}}}{12}\left(2 \mathrm{r}_{\mathrm{a}}+\mathrm{h}_{\mathrm{e}}\right) \\
& \mathrm{K}_{12}^{\mathrm{e}}=\mathrm{K}_{21}^{\mathrm{e}}, \mathrm{K}_{22}^{\mathrm{e}}=\frac{\mathrm{a}_{\mathrm{e}}}{\mathrm{h}_{\mathrm{e}}}\left(\mathrm{r}_{\mathrm{a}}+\frac{\mathrm{h}_{\mathrm{e}}}{2}\right)+\frac{M h_{\mathrm{e}}}{12}\left(4 \mathrm{r}_{\mathrm{a}}+3 \mathrm{~h}_{\mathrm{e}}\right), \mathrm{f}_{1}^{\mathrm{e}}=\frac{\mathrm{f}_{\mathrm{e}} \mathrm{h}_{\mathrm{e}}}{6}\left(3 \mathrm{r}_{\mathrm{a}}+\mathrm{h}_{\mathrm{e}}\right), \mathrm{f}_{2}^{\mathrm{e}}=\frac{\mathrm{f}_{\mathrm{e}} \mathrm{h}_{\mathrm{e}}}{6}\left(3 \mathrm{r}_{\mathrm{a}}+2 \mathrm{~h}_{\mathrm{e}}\right) \\
& \text { Thus, }\left[\mathrm{K}^{\mathrm{e}}\right]=\frac{\mathrm{a}_{\mathrm{e}}}{\mathrm{h}_{\mathrm{e}}}\left(\mathrm{r}_{\mathrm{a}}+\frac{\mathrm{h}_{\mathrm{e}}}{2}\right)\left[\begin{array}{cc}
1 & -1 \\
-1 & 1
\end{array}\right]+\frac{\mathrm{Mh}_{\mathrm{e}}}{12}\left[\begin{array}{cc}
4 \mathrm{r}_{\mathrm{a}}+\mathrm{h}_{\mathrm{e}} & 2 \mathrm{r}_{\mathrm{a}}+\mathrm{h}_{\mathrm{e}} \\
2 \mathrm{r}_{\mathrm{a}}+\mathrm{h}_{\mathrm{e}} & 4 \mathrm{r}_{\mathrm{a}}+3 \mathrm{~h}_{\mathrm{e}}
\end{array}\right] \text { and }\left\{\mathrm{f}^{\mathrm{e}}\right\}=\frac{\mathrm{f}_{\mathrm{e}} \mathrm{h}_{\mathrm{e}}}{6}\left[\begin{array}{c}
3 \mathrm{r}_{\mathrm{a}}+\mathrm{h}_{\mathrm{e}} \\
3 \mathrm{r}_{\mathrm{a}}+2 \mathrm{~h}_{\mathrm{e}}
\end{array}\right]
\end{aligned}
$$

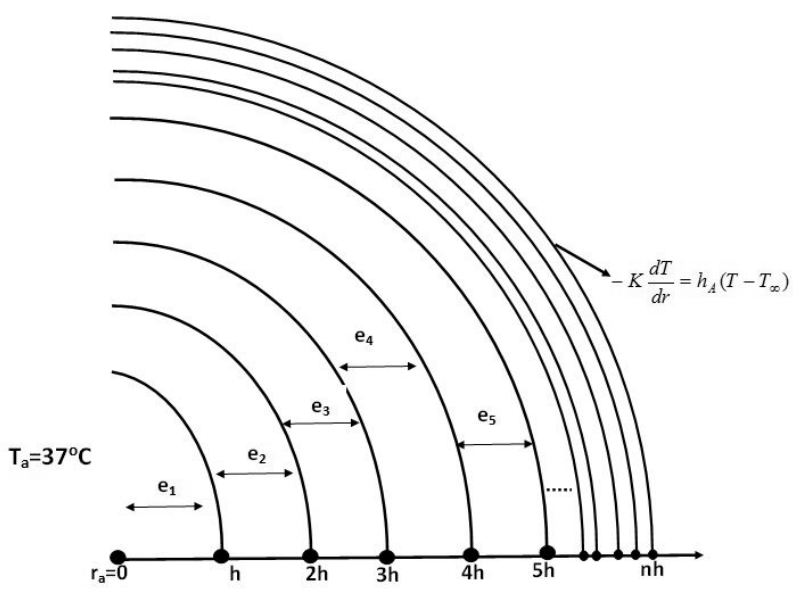

Fig 1 Finite Element Discretisation Mesh. 
From the equation(7) we find the element at $r_{a}=0, h, 2 h, \ldots, n h$ and assembling the elements in the matrix form; $\mathrm{PX}=\mathrm{Q}(8)$ where, $\mathrm{P}=\left[\begin{array}{ccccc}\mathrm{a} & \mathrm{c} & 0 & \cdots & 0 \\ \mathrm{c} & 4 \mathrm{~b} & 3 \mathrm{c} & \cdots & 0 \\ 0 & 3 \mathrm{c} & 8 \mathrm{~b} & 5 \mathrm{c} & 0 \\ 0 & 0 & \vdots & \ddots & \vdots \\ 0 & 0 & 0 & \cdots & \mathrm{p}\end{array}\right], \mathrm{X}=\left[\begin{array}{c}\mathrm{T}_{1} \\ \mathrm{~T}_{2} \\ \mathrm{~T}_{3} \\ \vdots \\ \mathrm{T}_{\mathrm{n}}\end{array}\right]$ and $\mathrm{Q}=\mathrm{N}\left[\begin{array}{c}1 \\ 6 \\ 12 \\ \vdots \\ \mathrm{v}_{1}\end{array}\right]+\left[\begin{array}{c}\mathrm{Q}_{1}^{1} \\ \mathrm{Q}_{1}^{2}+\mathrm{Q}_{2}^{1} \\ \mathrm{Q}_{1}^{3}+\mathrm{Q}_{2}^{2} \\ \vdots \\ \mathrm{Q}_{2}^{\mathrm{n}}\end{array}\right]$ and $\quad \mathrm{a}=\frac{6 \mathrm{~K}+\mathrm{Mh}^{2}}{12}, \mathrm{~b}=\frac{6 \mathrm{~K}+2 \mathrm{Mh}^{2}}{12}, \mathrm{c}=\frac{-6 \mathrm{~K}+\mathrm{Mh}^{2}}{12}, \mathrm{p}=6 \mathrm{~K}(2 \mathrm{n}-1)+\left((4 \mathrm{n}-1) \mathrm{Mh}^{2}\right), \mathrm{N}=\frac{\mathrm{fh}^{2}}{6}, \mathrm{v}_{1}=(3 \mathrm{n}-1)$

For the boundary condition of extreme points of each linear element

$$
\mathrm{P}=\left[\begin{array}{ccccc}
\mathrm{a} & \mathrm{c} & 0 & \cdots & 0 \\
\mathrm{c} & 4 \mathrm{~b} & 3 \mathrm{c} & \cdots & 0 \\
0 & 3 \mathrm{c} & 8 \mathrm{~b} & 5 \mathrm{c} & 0 \\
0 & 0 & \vdots & \ddots & \vdots \\
0 & 0 & 0 & \cdots & \alpha
\end{array}\right], \mathrm{X}=\left[\begin{array}{c}
\mathrm{T}_{1} \\
\mathrm{~T}_{2} \\
\mathrm{~T}_{3} \\
\vdots \\
\mathrm{T}_{\mathrm{n}}
\end{array}\right] \text { and } \mathrm{Q}=\mathrm{N}\left[\begin{array}{c}
1 \\
6 \\
12 \\
\vdots \\
\mathrm{v}_{1}
\end{array}\right]+\left[\begin{array}{c}
0 \\
0 \\
0 \\
\vdots \\
\beta
\end{array}\right]
$$

where, $\alpha=p+R_{A} T_{n+1}, \beta=R h_{A} T_{\infty}$.

\section{Numerical Results and Discussion}

This section discusses the effects of thermal conductivity in living tissue using the Galerkin Finite element solution equation. These numerical results of these effects based on the discussed solution techniques, we consider the following parameter values[9] with normal ambient temperature $\left(T_{\infty}\right) 25^{0} \mathrm{C}$ and number of nodes 30 .

Table 1 Values of Parameters for Theoretical Analysis.

\begin{tabular}{|c|c|c|c|c|c|c|}
\hline $\begin{array}{c}\mathrm{w}_{\mathrm{b}} \\
\mathrm{Kg} / \mathrm{s} \cdot \mathrm{m}^{3}\end{array}$ & $\begin{array}{c}\mathrm{c}_{\mathrm{b}} \\
\mathrm{J} / \mathrm{Kg} .{ }^{0} \mathrm{C}\end{array}$ & $\begin{array}{c}\mathrm{K} \\
\mathrm{W} / \mathrm{m} .{ }^{0} \mathrm{C}\end{array}$ & $\begin{array}{c}\mathrm{h}_{\mathrm{A}} \\
\mathrm{W} / \mathrm{m}^{2}{ }^{0} \mathrm{C}\end{array}$ & $\begin{array}{c}\mathrm{q}_{\mathrm{m}} \\
\mathrm{W} / \mathrm{m}^{3}\end{array}$ & $\begin{array}{c}\mathrm{T}_{\mathrm{a}} \\
{ }^{0} \mathrm{C}\end{array}$ & $\begin{array}{c}\mathrm{R} \\
\mathrm{m}\end{array}$ \\
\hline 3 & 3850 & 0.48 & 10.023 & 1085 & 37 & 0.0285 \\
\hline
\end{tabular}

\section{Effects of the Thermal Conductivity}

The various value of thermal conductivity of dermal part are taken as $0.24 \mathrm{~W} / \mathrm{m} .{ }^{0} \mathrm{C}, 0.48 \mathrm{~W} / \mathrm{m} .{ }^{0} \mathrm{C}$ and $0.72 \mathrm{~W} / \mathrm{m} .{ }^{0} \mathrm{C}$ for the observation of the thermal conductivity effects in living tissue. Figure(1) represent the graph of thickness verses body temperature obtained by using FEM solution. 


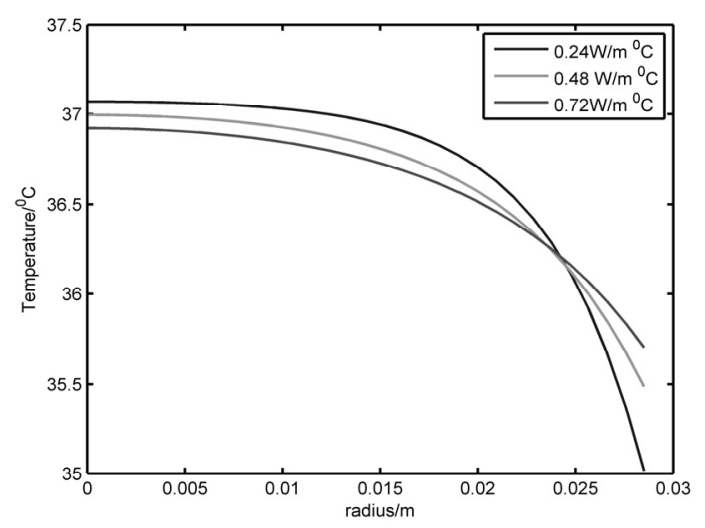

Fig 2 Effects of the Thermal Conductivity.

The observed results in Figure shows that the temperature distribution in living tissue is decreasing smoothly and then temperature falls sharply nearly the skin surface due to the conduction process at the outer surface of the living tissue. The value of temperature at any point of dermal part near core at high thermal conductivity is less than the temperature at low thermal conductivity. The results obtained from Figure exhibit approximately the same value of temperature distribution at a given thickness of dermal part measured from the body core.

\section{Conclusion}

In this study we use the different thermal parameters with their different values of thermal conductivity of the dermal part of living tissue. The effects of different thermal parameters are discussed by using Galerkins FEM solution method in the cylindrical bio-heat equation. The effects of thermal conductivities have the significant and more remarkable effects in temperature variation in living tissue.

The solution obtained can be used for the measurement of thermal parameters, reconstruction of the temperature field and thermal diagnosis and in the treatment that maximizes the therapeutic effect while minimizing unwanted side effect. It may also be useful to design medical devices to perform within a special range of temperature rate of heating and cooling. 


\section{References}

1. S. Acharya and D. B. Gurung, "Five Layered Temperature Distribution in Human Dermal Part”, Nepali Mathematical Sciences Report 31, (2011), no. 1-2, pp. 15-28.

2. T. E. Cooper and G. J. Trezek, “A Probe Technique for Determining the Thermal Conductivity of Tissue”, J. Heat transfer, ASME, 94(1972)133.

3. D. B. Gurung, "Mathematical Study of Abnormal Thermoregulation in Human Dermal Parts", Ph. D. Thesis, (2007).

4. D. B. Gurung ,V. P. Saxena, and P. R. Adhikari , "Finite Element Approach to One Dimensional Unsteady State Temperature Distribution in the Dermal Parts with Quadratic Shape Function”, J. Appl. Math \& Information, (2009), 27, pp. 301-313.

5. C. Guyton and E. Hall , “Text Book of Medical Physiology”, Elsevier, India, (2009).

6. M. N. Ozisik, "Heat conduction”, John Wiley \& Sons Inc., Second Edition (1993), pp. 436-495.

7. H. H. Pennes, "Analysis of Tissue and Arterial Blood Temperature in Resting Human Forearm”, A Journal of Applied Physiology, (1948), 1(2), pp. 657-678.

8. J. N. Reddy, “An Introduction to Finite Element Method”, McGraw Hill Publishing Company Limited, Third Edition, (2006), pp. 1-180.

9. K. Y. X. Zhang and F. Yu, "An Analytic Solution of One-Dimensional Steady-State Pennes Bioheats Transfer Equation in Cylindrical Coordinates”, Journal of thermal Science, (2004), 13(3), pp. 255-258. 